\title{
$1^{++}$등급 거세한우의 부위별 이화학적 육질특성 및 영양성분조성
}

\author{
조수현* · 김진형 - 성필남 - 조영무 · 정완태 - 박범영 - 정명옥 - 김동훈 - 이종문 · 안종남 \\ 농촌진흥청 축산과학원
}

\section{Physico-chemical Meat Quality Properties and Nutritional Composition of Hanwoo Steer Beef with $1^{++}$Quality Grade}

\author{
S. H. Cho*, J. H. Kim, P. N. Seong, Y. M. Cho, W. T. Chung, B. Y. Park, M. O. Chung, \\ D. H. Kim, J. M. Lee, and C. N. Ahn \\ National Institute of Animal Science, RDA, Suwon 441-706, Korea
}

\begin{abstract}
This study was conducted to investigate the nutritional composition and meat quality properties of Hanwoo steer beef by different cut. Ten cuts [Abjin (short plate), Bosup (top sirloin), Cheggt (striploin), Dngsim (loin), Guri (chuck tender), Hongduke (eye of round), Moksim (chuck roll), Sulgit (bottom round), Udoon (top round), Yangii (brisket)] prepared from 10 Hanwoo steers (28-30 months old) were used for this experiment. The range of $\mathrm{pH}$ was 5.46-5.64. In the chemical analysis, Hongduke contained highest protein contents $(21.15 \%)$ and Dngsim had lowest protein contents $(16.94 \%)(p<0.05)$. Fat contents were higher in Dngsim whereas those of Guri, Hongduke and Udoon were significantly lower when compared to the other cuts $(p<0.05)$. There were not significantly different in meat color $(\mathrm{L}, \mathrm{a}$ and $\mathrm{b}$ values) properties only except that L values were significantly higher in Dngsim among 10 cuts $(p<0.05)$. Cooking loss (\%) was higher in Guri, Hongduke, Udoon and Yangii whereas it was significantly lower in Cheggt $(p<0.05)$. Warner-Bratzler shear force (WBS) was significantly higher in Abjin $\left(6.24 \mathrm{inch}^{2} / \mathrm{kg}\right)$, whereas Dngsim $\left(3.45 \mathrm{inch}^{2} / \mathrm{kg}\right)$ and Cheggt $\left(3.50 \mathrm{inch}^{2} / \mathrm{kg}\right)$ were significantly lower than the other cuts $(p<0.05)$. There was no significant difference in water-holding capacity (WHC) among 10 cuts $(p>0.05)$. Total amino acid contents were significantly higher in Hongduke $(p<0.05)$. Hongduke was highest in most kinds of amino acids, however, Udoon had the highest methionine and histidine contents among 10 cuts $(p<0.05)$. Glutamate contents were high in all cuts and followed by aspartate, leucine and lysin. With regard to mineral contents, Ca was ranged from 47.63$70.69 \mathrm{mg} / \mathrm{kg}$ and $\mathrm{Fe}$ was ranged from $15.09-26.68 \mathrm{mg} / \mathrm{kg}$ in 10 cuts. Zn was highly contained in Guri $(50.56 \mathrm{mg} / \mathrm{kg}$ ) when compared to the other cuts $(p<0.05)$.
\end{abstract}

Key words : Hanwoo steer beef, meat quality, nutritional property

\section{서 론}

국내 소사육두수는 2007년 12월을 기준으로 총 2,653,976 두인데 그 중에서 한우가 $2,200,573$ 두이고 젖소가 453,403 두로 보고되었으며, 도축하여 등급판정을 받은 물량으로 는 한우가 492,115두, 젖소가 67,600두, 육우가 122,166두 로 보고되었다(APGS, 2008). 한우의 경우 암소가 211,661 두(45.04\%)로 가장 많았고 그 다음이 거세우로 169,912 두 (34.53\%)였으며 수소가 가장 낮은 110,542 두 $(22.46 \%)$ 로 나

*Corresponding author : S. H. Cho, Quality Control and Utilization of Animal Products Division, National Institute of Animal Science, Suwon 441-350, Korea. Tel: 82-31-290-1703, Fax: 82-31-290-1697, E-mail: shc0915@rda.go.kr
타났다. 거세우의 평균 도체중량은 $347.89 \mathrm{~kg}$ 으로 수소와 암소가 각각 $365.13 \mathrm{~kg}$ 및 $254.51 \mathrm{~kg}$ 수준인 것과 비교하 여 중간정도이며 고기생산량도 도체중량의 약 $69.29 \%$ 정 도여서 수소와 암소가 각각 $72.92 \%, 69.71 \%$ 인 것과 비교 하여 중간정도인 것으로 나타났다. 육류등급제는 소비자 가 가장 객관적으로 고기의 품질을 판단할 수 있는 방법 으로 선진국에서도 이 제도를 도입하여 등급에 따라 차등 판매를 하고 있다(National Livestock and Meat Board, 1988). 현재 우리나라에서 실시되고 있는 도체등급제도의 경우 육량등급은 도체중, 등지방두께, 등심단면적 등을 측 정하여 판정하고 있으며 육질등급은 근내지방도, 육색, 지 방색, 조직감 및 성숙도 등을 측정하여 판정하고 있다. 현 행 육질등급은 5 개 $\left(1^{++}, 1^{+}, 1,2,3\right)$ 로 나뉘어져 있다. 2007 
년도 축종별 등급출현율을 보면 1 등급이상 출현율이 한우 가 $47.3 \%$, 육우가 $10.9 \%$, 젖소가 $1 \%$ 수준으로 한우가 등 급출현율이 월등히 높았으며, 한우고기에서도 성별로 나 누어 1 등급이상 출현율을 분석한 결과 거세우가 $71.5 \%$, 암소가 $59.7 \%$ 인데 반하여 수소는 $2.9 \%$ 수준으로 거세우 가 가장 높았다. 거세우와 암소를 비교했을 때 $1^{\text {t+ }}$ 등급 출현두수는 전체 한우도축두수 492,115두 중에서 $7.5 \%$ 수 준이었는데 이 중에서 암소가 211,661 두 중에서 18,397 두, 거세우가 169,912 두 중에서 18,601 두로서 $1^{++}$등급 출현율 이 각각 $8.7 \%, 10.9 \%$ 로서 거세우의 고급육 생산율이 암 소보다도 높은 것으로 보고되었다(APGS, 2008). 한우고기 는 대부분 농후사료로 키우는데 일반적으로 농후사료로 키운 거세우는 초지사료로 키운 경우보다 육질이 더 연하 고(Chrystall, 1994), 육색(Baardseth et al., 1988)과 다즙성 (Hutchings and lllford, 1988) 및 향미(Melton, 1990)가 더 우수한 것으로 알려져 있다. 쇠고기의 육질을 평가하는 요 인으로는 근육의 연도, 육색, 보수성, 가열감량 및 근내지 방도(intramuscular fat contens)가 중요시 된다(김 등, 2007).

한편, 국내 쇠고기 부위별 상품은 대분할 10 개 부위 및 소분할 39개 부위로 나누어져 있으며(농림부고시 제 200782호) 부위마다 성분조성 및 육질 차이로 인해 요리방법 이나 용도가 다양하게 이용되고 있다. 등급 판정 및 육질 특성의 가장 기본이 되는 등심이나 채끝부위는 고기의 결 이 가늘고 육질이 좋고 적당한 지방이 침착되어 있어 조 리시 연도와 풍미가 좋은 반면에 목심부위는 운동량이 많 은 부위로 근인대가 많은 부위이다(농림기술개발사업최종 보고서, 2001). 쇠고기는 부위에 따라 육질에 차이가 있는 데 운동을 많이 하는 위치에 있는 근육은 근원섬유, 근섬 유, 근섬유다발 등을 감싸고 있는 결체조직들이 잘 발달 되어 단단하고 질긴고기를 생산하게 된다. 다리근육들은 비교적 질기고 몸통부위 근육들이 대부분 부드러운 고기 를 생산하게 되는 것이다(김 등, 2007), 운동을 적게 하는 부위 근육에는 근섬유사이에 지방축적이 잘 발달되지만 운동을 많이 하는 부위근육은 근막과 근섬유의 막이 잪 발달하고 지방의 축적정도가 매우 낮아 이러한 근육들간 에는 육질차이가 나게 되는 것이다. 운동량이 상대적으로 적은 등심, 안심, 갈비부위 등의 근육들은 결합조직의 발 달이 적고 근육과 근섬유사이에 지방조직들이 잘 발달하 여 연하고 풍미가 우수한 고기를 생산한다(김 등, 2007). 한편, 부분육간의 육질차이는 가축들의 품종, 성, 연령, 운 동량, 영양상태, 도축 후 사후처리 및 저장상태 등에 다양 한 조건에 의해서도 영향을 받는다. 양지머리부위는 근육 과 지방교합이 좋으면서 고기가 얇고 단단한 반면 업진부 위는 호흡시 운동하는 근육으로 다소 결이 거칠고 질기지 만 지방과 적육이 혼합되어 풍미가 좋은 것으로 알려져 있다. 설깃부위는 적육이 많고 근섬유가 거칠고 단단하며 우둔은 지방이 적고 적육이 많으며 고기결이 거칠다. 한
편 보섭부위는 육색이 선명하고 결은 가늘지만 지방과 적 육비율이 적절하고 또한 등심보다 연하여 스테이크로 이 용되는 부위이다(김 동, 2007). 이와 같이 각 부위별 근육 내 성분조성 및 근육특성에 따라 다양한 육질특성을 가지 고 있다는 것은 잘 알려져 있음에도 불구하고 현재까지 쇠고기 연구는 주로 등심이나 우둔부위 위주로 특성을 조 사하는 경향이었다. 또한, 품종별 도체 및 쇠고기의 이화 학적 특성에 대한 연구는 국내에서도 다수 수행되었으나 (김과 오, 1990; 강 등, 1992; 유 등, 1993; Kim et al,, 1996) 고급육 생산에 필요한 국내 최상의 육질등급을 가 진 거세한우고기에 대하여 부위별 육질 및 성분조성에 대 한 특성비교 연구는 거의 없는 실정이다. 따라서 본 연구 의 목적은 거세한우고기 중 국내에서 최고의 고급육으로 유통되고 있는 $1^{++}$육질등급 한우고기의 부위별 성분조성 및 육질특성을 조사하고자 거세우 10 두에서 10 부위를 선 정하여 성분조성 및 육질특성을 분석하였다.

\section{재료 및 방법}

\section{공시재료}

본 연구에 사용된 시료는 가락동 공판장에서 타격법 (captive bolt pistol)과 일반현수법(Achilles tendon hanging method)을 이용하여 도축된 물량 중에서 등급판정사로부 터 $1^{++}$육질등급을 판정받은 거세한우(28-30개월) 10 두를 구입하여 이용하였다. 도축 후 도체는 $1^{\circ} \mathrm{C}$ 냉각실에 저장 하였다가 다음 날 반도체 상태로 축산과학원 육가공장으 로 냉장 상태로 운송되었으며 운송된 도체들은 농림부고 시(제 2005-50호)에 따라 제작된 '쇠고기 및 돼지고기 부 분육 분할정형지침서'(1997)에 제시된 쇠고기 부분육 분할 정형방법에 준하여 총 10 부위(등심, 채끝, 목심, 꾸리, 업 진, 양지머리, 설깃, 보섭, 흥두깨 및 우둔)를 분리하였다. 시료들은 부위별로 구분하여 진공 포장 $(350 \times 700 \mathrm{~mm}$, Cryovac ${ }^{\circledR}$, Sealed Air Ltd. USA)한 다음 $2^{\circ} \mathrm{C}$ 숙성실에서 7일간 숙성시키고 분석에 이용하였다.

\section{$\mathrm{pH}$ 분석}

$\mathrm{pH}$ 는 각 부위의 중심부에 $\mathrm{pH}$ meter(pH-K21, NWK-Binär $\mathrm{GmbH}$ Co., Germany)를 이용하여 측정하였다.

\section{일반성분 분석}

단백질, 수분, 지방, 회분 분석은 $\mathrm{AOAC}(1995)$ 에 준하여 분석하였다. 지방 및 수분함량은 CEM 자동추출장치 (Labwave 9000/FAS 9001, CEM Corp., Matthews, NC, USA)를 이용하여 측정하였다. 단백질은 Kjeltec System (Kjeltec Auto 2400/2460, Foss Tecator AB, Höganas, Sweden)을 이용하여 분석하였으며, 회분은 회분분석기 (MAS 7000, CEM Corp., Matthews, NC, USA)를 이용하 
여 측정하였다.

\section{가열감량, 보수력 및 전단력}

보수력(Water-holding capacity; WHC)은 원심 분리법 (Ryoichi et al., 1993)으로 측정하였으며, 가열감량(Cooking loss)은 각 부위의 근육을 $2.5 \mathrm{~cm}$ 두께의 스테이크 모양으 로 절단하고 $80^{\circ} \mathrm{C}$ 항온수조에서 시료의 심부온도가 $70^{\circ} \mathrm{C}$ 에 도달할 때까지 가열한 후 가열전후 중량차를 백분율로 계산하였으며 가열한 시료는 Wheeler 등(2000)의 방법을 이용하여 전단력가(WBS, Warner-Bratlzer shear force) 측 정시료로 사용하였다.

\section{육 색}

육색은 Chromameter(CR301, Minolta Co., Germany)로 명도 $(\mathrm{L})$, 적색도(a), 황색도(b)를 $\mathrm{CIE}(\mathrm{Commision}$ Internationale de Leclairage) 값으로 측정하였으며 이때 사용한 표준판은 $\mathrm{Y}=92.40, \mathrm{x}=0.3136, \mathrm{y}=0.3196$ 의 백색타일을 이 용하였다.

\section{아미노산 분석}

아미노산 분석을 위하여 고기시로 $5 \mathrm{~g}$ 와 $6 \mathrm{~N} \mathrm{HCl} 40 \mathrm{~mL}$ 를 둥근플라스크에 넣고 혼합한 다음 $110^{\circ} \mathrm{C}$ 에서 24 시간동 안 질소가스를 주입하여 가수분해하였다. 염산을 $50^{\circ} \mathrm{C}$ 에 서 증발농축시킨 다음 농축시료는 $0.2 \mathrm{~N}$ Sodium citrate buffer(pH 2.2) $50 \mathrm{~mL}$ 를 넣어 희석시킨 다음 여과지 $(0.45$ $\mu \mathrm{m})$ 로 여과하였다. 여과한 시료 $(30 \mu \mathrm{L})$ 는 아미노산 분석 기(Model 835, Hitachi, Japan)를 이용하여 분석하였다.

\section{무기물 분석}

무기물함량은 $\mathrm{AOAC}(1995)$ 방법에 준하여 측정하였다. 고기시료 $5 \mathrm{~g}$ 을 크루시블에 취하고 전기회화로(MAS-7000, CEM Corporation, USA) $600^{\circ} \mathrm{C}$ 에서 12 시간 이상 회화시 킨 뒤 방냉시키고 염산용액 $\left(\mathrm{HCl}: \mathrm{H}_{2} \mathrm{O}=1: 1\right) 10 \mathrm{~mL}$ 를 가 하여 하룻밤 방치하여 용해시킨 다음 여과지(Whatman No. 6)로 여과하여 시료액을 제조하였다. 무기물 분석은 칼숨, 철, 아연 함량을 분석하기 위해서 각각 표준용액을 제조 하고 원자홉광광도계(ICP Spectrophotometer, Spectroflame, Spectro Company, Germany)를 이용하여 칼슘은 $317.9 \mathrm{~mm}$, 철은 $259.4 \mathrm{~nm}$, 아연은 $213.9 \mathrm{~nm}$ 에서 흡광도를 측정하고 표준검량곡선을 각각 작성하여 함량 $(\mathrm{mg} / \mathrm{kg})$ 을 계산하였다.

$$
\begin{aligned}
& \text { 무기물함량 }(\%)= \\
& \frac{\text { 시료액의 흡광도 } / 1 \mathrm{ppm} \text { 기준흡광도 } \times \text { 회석배수 }}{\text { 시료중량 }(\mathrm{g}) \times 10^{6}} \times 100
\end{aligned}
$$

\section{통계분석}

분석결과는 SAS(1996) program-을 이용하여 Student-
Newman-Keul's 다중검정법으로 각 요인간의 유의성 $(p<0.05)$ 을 비교하였다.

\section{결과 및 고찰}

\section{$\mathrm{pH}$}

10 부위의 $\mathrm{pH}$ 는 5.46-5.64 범위였으며 꾸리부위가 5.64로 가장 높았던 반면에 보섭, 채끝, 및 우둔이 각각 $5.49,5.46$, 5.47 로 다른 부위와 비교했을 때 가장 낮게 나타났다 $(p<0.05)$ (Table 1). 최종 $\mathrm{pH}$ 는 영양상태, 수송거리, 계절, 다른 우군의 혼합 등, 도살 당시의 글리코겐의 농도에 영 향을 받는데(김 등 2007), 본 연구에 사용된 수소의 부위 별 $\mathrm{pH}$ 결과는 모두 정상범위에 속하는 것으로 나타났다. 강 등(1999)은 3등급 한우고기가 1등급 및 2등급 한우고 기와 비교하여 $\mathrm{pH}$ 가 높았다고 보고하였는데 본 연구에서 도 Cho 등(2007)이 3등급 한우수소의 $\mathrm{pH}$ 를 분석한 결과 5.62-5.75의 범위를 나타냈다는 결과와 비교했을 때 $1^{++}$등 급 거세한우의 $\mathrm{pH}$ 가 더 높은 경향을 나타내는 것으로 분 석되었다. Weninger과 Steinhauf(1968)와 Watson(1969)의 보고에 의하면 수소와 거세우의 미오글로빈 함량은 비슷 하다고 하였으나 사실상 수소가 공격적이고 쉽게 스트레 스를 받는 기질이 있어 높은 $\mathrm{pH}$ 와 함께 거세우보다 암적 색육 발생이 더 많다고 하였다(Field, 1971). 한편, Kim 등 (1996)은 쇠고기의 $\mathrm{pH}$ 값이 품종, 성 및 부위별에 따른 유

Table 1. pH and chemical composition (\%) of Hanwoo steer beef with $1^{++}$grade by different cut $(n=10)$

\begin{tabular}{cccccc}
\hline \hline Cut & $\mathrm{pH}$ & $\begin{array}{c}\text { Protein } \\
(\%)\end{array}$ & $\begin{array}{c}\text { Moisture } \\
(\%)\end{array}$ & $\begin{array}{c}\text { Fat } \\
(\%)\end{array}$ & $\begin{array}{c}\text { Ash } \\
(\%)\end{array}$ \\
\hline \multirow{2}{*}{ Apjin } & ${ }^{1} 5.58^{\mathrm{abc}}$ & $17.77^{\mathrm{de}}$ & $61.35^{\mathrm{c}}$ & $19.55^{\mathrm{b}}$ & $0.67^{\mathrm{ab}}$ \\
& $(0.03)$ & $(0.57)$ & $(1.35)$ & $(1.86)$ & $(0.03)$ \\
Bosup & $5.49^{\mathrm{cd}}$ & $19.69^{\mathrm{abc}}$ & $65.95^{\mathrm{ab}}$ & $13.31^{\mathrm{cd}}$ & $0.76^{\mathrm{a}}$ \\
& $(0.02)$ & $(0.44)$ & $(1.19)$ & $(1.66)$ & $(0.03)$ \\
Cheggt & $5.46^{\mathrm{d}}$ & $17.84^{\mathrm{de}}$ & $59.36^{\mathrm{c}}$ & $20.95^{\mathrm{ab}}$ & $0.7^{\mathrm{ab}}$ \\
& $(0.01)$ & $(0.45)$ & $(1.19)$ & $(1.59)$ & $(0.03)$ \\
Dngsim & $5.57^{\mathrm{abc}}$ & $16.94^{\mathrm{e}}$ & $58.17^{\mathrm{c}}$ & $24.74^{\mathrm{a}}$ & $0.60^{\mathrm{b}}$ \\
& $(0.03)$ & $(0.54)$ & $(0.89)$ & $(0.85)$ & $(0.03)$ \\
Guri & $5.64^{\mathrm{a}}$ & $19.49^{\mathrm{abcd}}$ & $70.08^{\mathrm{a}}$ & $9.32^{\mathrm{d}}$ & $0.72^{\mathrm{ab}}$ \\
& $(0.04)$ & $(0.34)$ & $(0.47)$ & $(0.44)$ & $(0.02)$ \\
Hongduke & $5.51^{\mathrm{bcd}}$ & $21.15^{\mathrm{a}}$ & $69.75^{\mathrm{a}}$ & $7.81^{\mathrm{d}}$ & $0.76^{\mathrm{a}}$ \\
& $(0.02)$ & $(0.37)$ & $(0.93)$ & $(0.99)$ & $(0.04)$ \\
Moksim & $5.59^{\mathrm{ab}}$ & $18.80^{\mathrm{cd}}$ & $64.93^{\mathrm{b}}$ & $15.52^{\mathrm{c}}$ & $0.69^{\mathrm{ab}}$ \\
& $(0.02)$ & $(0.35)$ & $(1.49)$ & $(1.93)$ & $(0.02)$ \\
\multirow{2}{*}{ Sulgit } & $5.50^{\mathrm{bcd}}$ & $19.50^{\mathrm{abcd}}$ & $66.38^{\mathrm{ab}}$ & $12.50^{\mathrm{cd}}$ & $0.72^{\mathrm{ab}}$ \\
& $(0.02)$ & $(0.39)$ & $(1.25)$ & $(1.53)$ & $(0.03)$ \\
\multirow{2}{*}{ Udoon } & $5.47^{\mathrm{d}}$ & $20.57^{\mathrm{ab}}$ & $68.43^{\mathrm{ab}}$ & $9.21^{\mathrm{d}}$ & $0.79^{\mathrm{a}}$ \\
& $(0.02)$ & $(0.37)$ & $(0.98)$ & $(1.37)$ & $(0.04)$ \\
Yangji & $5.50^{\mathrm{bcd}}$ & $19.08^{\mathrm{bcd}}$ & $66.96^{\mathrm{ab}}$ & $12.88^{\mathrm{cd}}$ & $0.72^{\mathrm{ab}}$ \\
& $(0.02)$ & $(0.33)$ & $(0.72)$ & $(0.97)$ & $(0.03)$ \\
\hline
\end{tabular}

\footnotetext{
${ }^{\mathrm{a}-\mathrm{d}}$ Means within the same column having the different superscript were significantly different $(p<0.05)$.

${ }^{1)}$ Mean (S.E.).
} 
의한 차이를 나타내지 않았다고 보고하였으나 본 연구 결 과 $1^{++}$등급 거세우고기는 10 부위간의 $\mathrm{pH}$ 값을 비교했을 때 유의적인 차이가 있는 것으로 나타났다 $(p<0.05)$.

\section{일반성분}

$1^{t+}$ 등급의 거세우의 10 부위에 대한 일반성분조성을 분 석한 결과 단백질 함랑은 홍두깨 부위가 $21.15 \%$ 로 가장 높은 반면에 등심부위의 단백질 함량은 $16.94 \%$ 로 가장 낮 은 것으로 분석되었다 $(p<0.05)$. 이와는 반대로 지방함랑은 등심부위가 $24.74 \%$ 로 가장 높은 반면에 꾸리, 홍두깨 및 우둔부위의 지방함량은 다른 부위와 비교했을 때 유의적 으로 가장 낮은 수준을 나타냈다 $(p<0.05)$. 수분함량은 꾸 리 및 홍두깨 부위가 69.75 및 $70.08 \%$ 로 가장 높았고 업 진, 채끝 및 등심부위가 58.17-61.35\%로 유의적으로 가장 낮은 범위를 나타냈다 $(p<0.05)$. 회분함량은 0.60-0.79\% 범 위였으며 보섭, 홍두깨 및 우둔부위가 높은 수준이었던 반 면에 등심부위는 $0.60 \%$ 로 10 부위 중에서 가장 낮은 수준 으로 나타났다 $(p<0.05)$. Cho 등 $(2007)$ 이 3 등급 한우수소의 부위별 성분조성을 분석한 결과 지방함량이 등심 부위가 가장 높았고 홍두깨부위가 가장 낮은 경향을 나타냈다고 $(p<0.05)$ 보고하였는데 이러한 경향은 $1^{++}$등급의 거세한 우에서도 유사하게 분석되었다. $\mathrm{Kim}$ 등(2002)은 등급볋 품질특성 및 이화학적 성분조사에서 근내지방도만이 둥급 에 따른 유의적인 차이가 있었다고 보고하였다. 또한 3등 급 한우수소의 경우 부위별 수분함량이 74.03-75.82\% 범 위로 보고한 것과 비교했을 때 본 연구에서는 58.17-70.08\% 로 더 낮은 경항을 보였으며 이는 $1^{++}$등급 거세우의 부 위별 지방함랑이 수소보다 상대적으로 더 높았기 때문인 것으로 보인다. $\mathrm{Kim}$ 등(2002)은 육질등급별 한우 등심부 위의 일반성분을 분석한 결과 수분 함량이 근내지방 함량 이 가장 낮은 3 등급 수소에서 가장 놇은 수치를 보였다고 하였으며 근내지방도가 수분함량과는 부의 상관관계를 가 진다고 하였다. 근내지방함랑은 고기의 관능특성에 중오 한 영향을 미치는데 Eikelenboom 등(1996)은 고기의 근내 지방도가 관능특성 중에서 연도, 다즙성, 향미와 연관성이 있다고 하였으며(r=0.3), Flores 등(1999)도 근내지방도가 다즙성과 유의적인 관련성이 있다고 하였다. Rodrigues와 Andrade(2004)는 거세우의 등심에 지방함량이 $20.8 \%$ 로 지 방함량이 $9.9 \%$ 인 수소보다 상대적으로 높았으며 반대로 수분함량은 수소가 $71 \%$ 인 반면에 비거세우가 $73.6 \%$ 로 더 높은 것으로 나타났다. 수소고기가 지방함량이 낮고 단백질 함량이 높은 것은 testosterone 때문이며 testicular hormone이 수소의 근육량을 증가시키는 것과 관련된다고 보고하였다(Padre et al., 2006). 한편, 3등급 한우수소의 회 분함량은 홍두깨 부위가 가장 높았다고 $(p<0.05)$ 보고하였 는데 이는 본 연구에서도 유사한 경항을 보인 것으로 나 타닜다. $\mathrm{Kim}$ 등(1996)은 조지방 함량에서는 등심의 경우
거세한우가 수소보다 높게 나타났으며, 우둔부위가 등심 에 비하여 지방함량은 낮았는데 이러한 경향은 품종과 성 별에 관계없이 등심과 같은 경항을 나타내었다. 이는 품 종 및 성간에 수분함량과 지방함량간에 역의 관계가 있다 는 여러 연구자들과 일치하는 경향이었다(吉田 et al., 1968; Jacobs et al., 1977; Landon et al., 1978; 이 등, 1981; 백 등, 1992).

\section{육색}

$1^{++}$등급의 부위별 육색을 비교한 결과 L값(백색도)만이 등심부위가 유의적으로 가장 높게 나타났고 $(p<0.05)$ 다른 부위간에는 $\mathrm{L}$ 값, $\mathrm{a}$ 값(적색도) 및 $\mathrm{b}$ 값(황색도)에서 모두 유 의적인 차이가 없는 것으로 나타났다 $(p>0.05)$. Cho 등(2007) 이 3 등급 한우수소의 부위별 육색을 비교한 결과 업진이 $\mathrm{L}$ 값과 $\mathrm{b}$ 값가 가장 높았고 채끝부위가 가장 낮은 것으로 나타났으며 $(p<0.05)$, 홍두깨 부위가 a값이 가장 녿은 것으 로 나타났다 $(p<0.05)$ 고 보고하였으나 $1^{++}$등급의 거세우에 대하여 동일한 부위에 대한 육색을 조사한 결과 이와는 상이한 경항을 보이는 것으로 나타났다. 3등급 수소의 경 우 L값이 33.53-40.28, a값이 16.16-21.08, b값이 6.71-11.11. 범위였다고 보고하였는데(Cho 등, 2007) $1^{++}$등급 거세한 우의 동일한 부위와 비교했을 때 L값이 38.78-42.67, a값 이 22.65-24.95, b값이 10.82-12.35 범위로서 3등급 수소 부위보다 $\mathrm{L}, \mathrm{a}, \mathrm{b}$ 값 모두 높은 범위인 것으로 나타났다. 우육의 육색과 지방색은 근내지방도와 함께 욱육의 육질 등급을 결정하는 주요 인자일 뿐만 아니라, 소비자의 구 매 관점에서도 대단히 중요하다(Ansorena et al., 1997; Mercier 등, 1998). 우리나라의 경우 육질등급 판정 시에 육색 및 지방색은 각각 No.1-No.7까지 분류하여 육색은 약한 선홍색에서 짙은 암적색까지, 지방색은 백색에서 황 색까지 분류하고 있다(강 등, 1999). 육색은 주로 마이오 글로빈(myoglobin)의 함량에 의존하며(Sakata and Nagata, 1992; Santamaria et al., 1992; Ibanez et al., 1995; Lizaso et al., 1996), 지방색은 비타민 $\mathrm{A}$ 의 전구체인 $\beta$-carotenoid 함량에 의존하는 바가 크다(Yang et al., 1992; Yang et al., 1999). 한편, 육색소인 myoglobin 함랑이 근내지방등급이 높아짐에 따라 그 함량이 줄어들고, 성별에 따라 비거세 우, 거세우, 미경산우 순으로 유의차 $(\mathrm{p}<0.001)$ 가 있었다고 보고된 바 있었다(Kim et al., 2002).

\section{가열감량, 보수력 및 전단력}

$1^{++}$등급 거세우고기의 10 부위의 가열감량을 분석한 결 과 꾸리, 홍두깨, 우둔, 양지부위가 $30.56,29.57,29.85$, $30.08 \%$ 가장 높은 수준으로 나타난 반면에 채끝부위가 $21.44 \%$ 로 유의적으로 가장 낮게 나타났다 $(p<0.05)$ (Table 2). 고기의 가열은 가열방법, 성분조성 및 익힘정도에 따 라 그 구조의 변화를 야기하며 가열방법에 관계없이 고기 
Table 2. Meat color (CIE L, a, b), cooking loss (CL), water holding capacity (WHC), Warner-bratzler shear force (WBS) of Hanwoo steer beef with $1^{++}$grade by different cut $(n=10)$

\begin{tabular}{|c|c|c|c|c|c|c|}
\hline \multirow{2}{*}{ Cut } & \multicolumn{3}{|c|}{ CIE } & \multirow{2}{*}{$\begin{array}{l}\mathrm{CL} \\
(\%)\end{array}$} & \multirow{2}{*}{$\begin{array}{c}\text { WBS } \\
\left(\text { inch }^{2} / \mathrm{kg}\right)\end{array}$} & \multirow{2}{*}{$\begin{array}{c}\text { WHC } \\
(\%)\end{array}$} \\
\hline & $\mathrm{L}$ & $\mathrm{a}$ & b & & & \\
\hline Apjin & $\begin{array}{c}1) 39.18^{b} \\
(0.38)\end{array}$ & $\begin{array}{l}24.49 \\
(1.55)\end{array}$ & $\begin{array}{l}11.30 \\
(0.87)\end{array}$ & $\begin{array}{c}27.70^{\mathrm{ab}} \\
(1.61)\end{array}$ & $\begin{array}{c}6.24^{\mathrm{a}} \\
(0.39)\end{array}$ & $\begin{array}{l}55.16 \\
(1.28)\end{array}$ \\
\hline Bosup & $\begin{array}{l}39.13^{\mathrm{b}} \\
(0.50)\end{array}$ & $\begin{array}{l}23.22 \\
(0.74)\end{array}$ & $\begin{array}{l}10.82 \\
(0.55)\end{array}$ & $\begin{array}{c}27.65^{\mathrm{ab}} \\
(1.21)\end{array}$ & $\begin{array}{l}4.64^{\mathrm{bc}} \\
(0.41)\end{array}$ & $\begin{array}{l}56.38 \\
(0.56)\end{array}$ \\
\hline Cheggt & $\begin{array}{l}40.85^{b} \\
(0.67)\end{array}$ & $\begin{array}{l}22.65 \\
(0.96)\end{array}$ & $\begin{array}{l}11.53 \\
(0.52)\end{array}$ & $\begin{array}{l}21.44^{\mathrm{d}} \\
(0.59)\end{array}$ & $\begin{array}{l}3.50^{c} \\
(0.32)\end{array}$ & $\begin{array}{l}57.07 \\
(1.00)\end{array}$ \\
\hline Dngsim & $\begin{array}{l}42.67^{\mathrm{a}} \\
(0.94)\end{array}$ & $\begin{array}{l}23.21 \\
(1.41)\end{array}$ & $\begin{array}{l}12.35 \\
(0.60)\end{array}$ & $\begin{array}{l}23.44^{\mathrm{cd}} \\
(0.93)\end{array}$ & $\begin{array}{c}3.45^{\mathrm{c}} \\
(0.27)\end{array}$ & $\begin{array}{l}57.41 \\
(0.89)\end{array}$ \\
\hline Guri & $\begin{array}{l}39.36^{\mathrm{b}} \\
(0.35)\end{array}$ & $\begin{array}{l}24.95 \\
(0.64)\end{array}$ & $\begin{array}{l}11.83 \\
(0.44)\end{array}$ & $\begin{array}{l}30.56^{\mathrm{a}} \\
(0.60)\end{array}$ & $\begin{array}{l}5.05^{a b} \\
(0.33)\end{array}$ & $\begin{array}{l}55.82 \\
(1.01)\end{array}$ \\
\hline Hongduke & $\begin{array}{l}40.19^{b} \\
(0.42)\end{array}$ & $\begin{array}{l}23.30 \\
(0.59)\end{array}$ & $\begin{array}{l}11.70 \\
(0.45)\end{array}$ & $\begin{array}{l}29.57^{\mathrm{a}} \\
(0.63)\end{array}$ & $\begin{array}{l}5.15^{\mathrm{ab}} \\
(0.16)\end{array}$ & $\begin{array}{l}55.87 \\
(0.35)\end{array}$ \\
\hline Moksim & $\begin{array}{l}39.81^{b} \\
(0.53)\end{array}$ & $\begin{array}{l}24.32 \\
(0.65)\end{array}$ & $\begin{array}{l}11.30 \\
(0.45)\end{array}$ & $\begin{array}{l}25.64^{\mathrm{bc}} \\
(0.92)\end{array}$ & $\begin{array}{l}4.68^{b c} \\
(0.41)\end{array}$ & $\begin{array}{l}55.27 \\
(1.20)\end{array}$ \\
\hline Sulgit & $\begin{array}{l}38.78^{b} \\
(0.34)\end{array}$ & $\begin{array}{l}23.71 \\
(0.93)\end{array}$ & $\begin{array}{l}11.56 \\
(0.61)\end{array}$ & $\begin{array}{c}28.42^{\mathrm{ab}} \\
(0.68)\end{array}$ & $\begin{array}{l}4.90^{\mathrm{ab}} \\
(0.35)\end{array}$ & $\begin{array}{l}56.07 \\
(1.03)\end{array}$ \\
\hline Udoon & $\begin{array}{l}38.51^{\mathrm{b}} \\
(0.22)\end{array}$ & $\begin{array}{l}23.64 \\
(0.63)\end{array}$ & $\begin{array}{l}11.22 \\
(0.39)\end{array}$ & $\begin{array}{l}29.85^{\mathrm{a}} \\
(0.72)\end{array}$ & $\begin{array}{l}5.34^{\mathrm{ab}} \\
(0.29)\end{array}$ & $\begin{array}{l}55.09 \\
(0.67)\end{array}$ \\
\hline Yangji & $\begin{array}{l}40.25^{\mathrm{b}} \\
(0.75)\end{array}$ & $\begin{array}{l}23.29 \\
(1.30)\end{array}$ & $\begin{array}{l}11.83 \\
(0.50)\end{array}$ & $\begin{array}{l}30.08^{\mathrm{a}} \\
(0.89)\end{array}$ & $\begin{array}{l}5.21^{\mathrm{ab}} \\
(0.35)\end{array}$ & $\begin{array}{l}54.21 \\
(1.26)\end{array}$ \\
\hline
\end{tabular}

${ }^{\mathrm{a}-\mathrm{c}}$ Means within the same column having the different superscript were significantly different $(p<0.05)$.

${ }^{1 /}$ Mean (SE).

가 가열될 때 근섬유의 수축과 근절의 단축은 보수력의 감소와 가열감랑을 나타내게 된다(Bower et al., 1987). 부 위별로 가열감량은 등심이 우둔에 비하여 낮아 백 등(1992) 과 김 등(1996)의 연구 결과와 일치하는 경향이었고, 근내 지방도가 높을수록 가열감량이 적다고 한 Breidenstein 등 (1968), 三律本 등(1987) 및 김과 오(1990)의 보고와도 일 치하는 경향이었다. Gullett 등(1996)은 가열감량이 고기 관능특성 중 연도, 씹힙성 및 육즙방출정도와 부의 상관 관계를 가진다고 하였는데 특히 수분방출정도가 가장 높 은 수준의 부의 상관관계를 가졌고 $(\mathrm{r}=-0.65)$ 씹힘성과는 가 장 적은 부의 상관관계를 가졌다고 보고하였다. 전단력은 업진부위가 $6.24 \mathrm{inch}^{2} / \mathrm{kg}$ 으로 가장 높게 나타났고 등심과 채끝부위가 각각 3.45 및 $3.50 \mathrm{inch}^{2} / \mathrm{kg}$ 으로 가장 낮게 나 타났다 $(p<0.05)$ (Table 2). 연도를 측정하는 방법에는 기기 를 이용하거나 훈련된 관능평가요원을 이용하는 객관적인 방법과 소비자 관능평가를 이용하는 주관적인 방법이 있 는데 Wheeler 등(2000)은 전단력과 연도가 부의 상관관계 가 있다고 보고하였다. 보수력은 10 부위간에 유의적인 차 이가 없는 것으로 나타났다 $(p>0.05)$. Table 2 에 나타난 바 와 같이 $1^{++}$등급 거세우의 전단력은 $3.45-6.24 \mathrm{~kg} / \mathrm{inch}^{2}$ 이 었고 보수력은 54.21-57.41\%였는데 이 수치는 Cho 등(2007) 이 3등급 수소의 부위별 전단력 및 보수력이 각각 6.94$8.22 \mathrm{~kg} / \mathrm{inch}^{2}, 51.99-55.85 \%$ 인 결과와 비교했을 때 거세우 가 수소보다 전단력은 낮으면서 보수력은 더 높다는 것을
알 수 있었다. Kim 등(2002)은 근내지방도가 보수력과 정 (+)의 상관관계를 가진다고 하였고, Berry(1993)는 근내지 방도가 높을수록 전단력이 낮아진다고 하였는데 이러한 경향은 본 연구결과와도 일치하였다. 한 등(1996)은 한우 고기를 육질등급 및 성별로 육질특성을 비교한 결과 가열 감량은 저장일수 및 부위에 관계없이 비거세 3 등급이 거 세 1등급보다 높았다고 하였으며 동일한 육질등급의 등심 에서 거세우가 암소보다 가열감량이 낮았다고 하였다. 또 한 근내지방도가 높을수록 둥심이 우둔보다 보수력이 우 수하다고 하였다. 또한 전단력에서 비거세 3 등급 등심이 거세 1 등급과 비교하여 경도가 높았다고 하였다. 본 연구 에서 부위별로는 등심 및 채끝부위의 경우 근육내 지방함 량이 다른 부위들과 비교하여 가장 높았고 반대로 전단력 수치는 가장 낮게 나타났다 $(p<0.05)$. 따라서 보수력은 근 내지방함량과 관계있는 것으로 나타났으며 품종 및 부위 에 관계없이 거세우가 비거세우에 비하여 보수력이 더 높 았고, 부위별로는 등심이 우둔에 비하여 높은 경향이었다 고 Kim 등(1996)의 보고와 일치하는 경향으로 생각된다.

\section{아미노산}

거세한우 $1^{++}$등급의 쇠고기에서 10 부위의 아미노산 조 성 및 함량은 Table 3 과 같았다. 총 아미노산 함량은 홍 두깨 부위가 가장 높게 나타난 반면에 채끝, 업진 및 등 심부위가 가장 낮게 나타났다 $(p<0.05)$. 모든 부위에 
Table 3. Amino acid compositions of Hanwoo steer beef with $1^{++}$grade by different cut $(n=10)$

\begin{tabular}{|c|c|c|c|c|c|c|c|c|c|c|}
\hline $\mathrm{Cut}^{*}$ & A & $\mathrm{B}$ & $\mathrm{C}$ & $\mathrm{D}$ & $\mathrm{G}$ & $\mathrm{H}$ & M & $S$ & $\mathrm{U}$ & $\mathrm{Y}$ \\
\hline Cys & $\begin{array}{l}0.20^{6} \\
(0.01)\end{array}$ & $\begin{array}{l}0.23^{\mathrm{ab}} \\
(0.01)\end{array}$ & $\begin{array}{l}0.21^{\mathrm{ab}} \\
(0.01)\end{array}$ & $\begin{array}{l}0.20^{b} \\
(0.01)\end{array}$ & $\begin{array}{l}0.22^{\text {ab }} \\
(0.01)\end{array}$ & $\begin{array}{c}0.24^{\mathrm{a}} \\
(0.01)\end{array}$ & $\begin{array}{l}0.21^{\mathrm{ab}} \\
(0.01)\end{array}$ & $\begin{array}{l}0.21^{\mathrm{ab}} \\
(0.01)\end{array}$ & $\begin{array}{c}0.23^{\mathrm{a}} \\
(0.01)\end{array}$ & $\begin{array}{l}0.21^{a b} \\
(0.01)\end{array}$ \\
\hline Meth & $\begin{array}{c}0.44^{\mathrm{b}} \\
(0.01)\end{array}$ & $\begin{array}{l}0.49^{\mathrm{ab}} \\
(0.02)\end{array}$ & $\begin{array}{l}0.48^{\mathrm{ab}} \\
(0.02)\end{array}$ & $\begin{array}{c}0.45^{b} \\
(0.02)\end{array}$ & $\begin{array}{l}0.48^{\mathrm{ab}} \\
(0.01)\end{array}$ & $\begin{array}{l}0.51^{\mathrm{ab}} \\
(0.01)\end{array}$ & $\begin{array}{l}0.46^{\mathrm{ab}} \\
(0.01)\end{array}$ & $\begin{array}{l}0.48^{\mathrm{ab}} \\
(0.02)\end{array}$ & $\begin{array}{c}0.52^{\mathrm{a}} \\
(0.01)\end{array}$ & $\begin{array}{l}0.47^{a b} \\
(0.02)\end{array}$ \\
\hline ASP & $\begin{array}{l}1.62^{\mathrm{d}} \\
(0.06\end{array}$ & $\begin{array}{l}1.85^{a b} \\
(0.05)\end{array}$ & $\begin{array}{l}1.66^{\mathrm{cd}} \\
(0.04)\end{array}$ & $\begin{array}{c}1.59^{\mathrm{d}} \\
(0.04)\end{array}$ & $\begin{array}{l}1.88^{\mathrm{abc}} \\
(0.05)\end{array}$ & $\begin{array}{c}1.99^{a} \\
(0.04)\end{array}$ & $\begin{array}{l}1.73^{b c d} \\
(0.02)\end{array}$ & $\begin{array}{l}1.82^{\mathrm{abc}} \\
(0.05)\end{array}$ & $\begin{array}{c}1.95^{\mathrm{a}} \\
(0.04)\end{array}$ & $\begin{array}{l}1.74^{\text {bcd }} \\
(0.04)\end{array}$ \\
\hline Thr & $\begin{array}{c}0.80^{\mathrm{e}} \\
(0.03)\end{array}$ & $\begin{array}{c}0.93^{\mathrm{abc}} \\
(0.02)\end{array}$ & $\begin{array}{l}0.83^{\mathrm{de}} \\
(0.02)\end{array}$ & $\begin{array}{c}0.80^{\mathrm{c}} \\
(0.02)\end{array}$ & $\begin{array}{c}0.91^{\mathrm{tcd}} \\
(0.02)\end{array}$ & $\begin{array}{c}1.00^{\mathrm{a}} \\
(0.02)\end{array}$ & $\begin{array}{c}0.85^{\mathrm{dc}} \\
(0.01)\end{array}$ & $\begin{array}{c}0.91^{\text {bed }} \\
(0.02)\end{array}$ & $\begin{array}{l}0.97^{\mathrm{ab}} \\
(0.02)\end{array}$ & $\begin{array}{l}0.86^{\text {cde }} \\
(0.02)\end{array}$ \\
\hline Ser & $\begin{array}{l}0.71^{\text {te }} \\
(0.02)\end{array}$ & $\begin{array}{l}0.81^{\mathrm{abc}} \\
(0.02)\end{array}$ & $\begin{array}{l}0.72^{\mathrm{de}} \\
(0.02)\end{array}$ & $\begin{array}{c}0.69^{\mathrm{c}} \\
(0.02)\end{array}$ & $\begin{array}{l}0.81^{\mathrm{abc}} \\
(0.02)\end{array}$ & $\begin{array}{c}0.87^{\mathrm{a}} \\
(0.02)\end{array}$ & $\begin{array}{l}0.77^{\text {cd }} \\
(0.01)\end{array}$ & $\begin{array}{l}0.80^{\mathrm{bc}} \\
(0.02)\end{array}$ & $\begin{array}{l}0.85^{\mathrm{ab}} \\
(0.02)\end{array}$ & $\begin{array}{l}0.77^{\mathrm{cd}} \\
(0.02)\end{array}$ \\
\hline Glu & $\begin{array}{l}2.69^{\mathrm{cd}} \\
(0.10)\end{array}$ & $\begin{array}{l}3.05^{\mathrm{ab}} \\
(0.08)\end{array}$ & $\begin{array}{l}2.67^{\text {cd }} \\
(0.09)\end{array}$ & $\begin{array}{l}2.59^{\mathrm{d}} \\
(0.07)\end{array}$ & $\begin{array}{l}3.10^{\mathrm{ab}} \\
(0.09)\end{array}$ & $\begin{array}{c}3.32^{\mathrm{a}} \\
(0.06)\end{array}$ & $\begin{array}{l}2.91^{b c} \\
(0.06)\end{array}$ & $\begin{array}{l}2.93^{b c} \\
(0.08)\end{array}$ & $\begin{array}{l}3.19^{\mathrm{ab}} \\
(0.08)\end{array}$ & $\begin{array}{l}2.89^{b c} \\
(0.08)\end{array}$ \\
\hline Gly & $\begin{array}{l}0.90^{b c} \\
(0.05)\end{array}$ & $\begin{array}{l}0.91^{\mathrm{bc}} \\
(0.03)\end{array}$ & $\begin{array}{l}0.81^{\mathrm{cd}} \\
(0.02)\end{array}$ & $\begin{array}{c}0.79^{\mathrm{d}} \\
(0.02)\end{array}$ & $\begin{array}{l}0.94^{\mathrm{ab}} \\
(0.02)\end{array}$ & $\begin{array}{c}1.05^{\mathrm{a}} \\
(0.03)\end{array}$ & $\begin{array}{l}1.01^{\mathrm{ab}} \\
(0.04)\end{array}$ & $\begin{array}{l}0.97^{a b} \\
(0.03)\end{array}$ & $\begin{array}{l}0.96^{\text {ab }} \\
(0.01)\end{array}$ & $\begin{array}{l}1.00^{a b} \\
(0.02)\end{array}$ \\
\hline Ala & $\begin{array}{l}1.07^{\mathrm{cd}} \\
(0.04)\end{array}$ & $\begin{array}{c}1.20^{b} \\
(0.03)\end{array}$ & $\begin{array}{l}1.07^{\mathrm{cd}} \\
(0.03)\end{array}$ & $\begin{array}{c}1.04^{\mathrm{d}} \\
(0.03)\end{array}$ & $\begin{array}{c}1.20^{\mathrm{b}} \\
(0.03)\end{array}$ & $\begin{array}{c}1.34^{\mathrm{a}} \\
(0.03)\end{array}$ & $\begin{array}{l}1.17^{b c} \\
(0.02)\end{array}$ & $\begin{array}{c}1.19^{b} \\
(0.03)\end{array}$ & $\begin{array}{l}1.27^{a b} \\
(0.02)\end{array}$ & $\begin{array}{l}1.17^{\mathrm{bc}} \\
(0.03)\end{array}$ \\
\hline Val & $\begin{array}{c}0.79^{\mathrm{d}} \\
(0.03)\end{array}$ & $\begin{array}{l}0.90^{\mathrm{bc}} \\
(0.02)\end{array}$ & $\begin{array}{l}0.82^{\text {cd }} \\
(0.02)\end{array}$ & $\begin{array}{c}0.79^{d} \\
(0.02)\end{array}$ & $\begin{array}{c}0.88^{\mathrm{bc}} \\
(0.02)\end{array}$ & $\begin{array}{c}0.98^{\mathrm{a}} \\
(0.02)\end{array}$ & $\begin{array}{l}0.83^{\mathrm{cd}} \\
(0.01)\end{array}$ & $\begin{array}{l}0.89^{b c} \\
(0.02)\end{array}$ & $\begin{array}{l}0.95^{\mathrm{ab}} \\
(0.02)\end{array}$ & $\begin{array}{l}0.84^{\mathrm{cd}} \\
(0.02)\end{array}$ \\
\hline Le & $\begin{array}{c}0.71^{\mathrm{d}} \\
(0.03)\end{array}$ & $\begin{array}{l}0.80^{\mathrm{abc}} \\
(0.02)\end{array}$ & $\begin{array}{l}0.73^{\text {cd }} \\
(0.02)\end{array}$ & $\begin{array}{c}0.71^{\mathrm{d}} \\
(0.02)\end{array}$ & $\begin{array}{c}0.79^{\text {bcd }} \\
(0.02)\end{array}$ & $\begin{array}{c}0.87^{\mathrm{a}} \\
(0.02)\end{array}$ & $\begin{array}{c}0.73^{\mathrm{d}} \\
(0.01)\end{array}$ & $\begin{array}{l}0.79^{\text {bcd }} \\
(0.02)\end{array}$ & $\begin{array}{l}0.85^{\text {ab }} \\
(0.02)\end{array}$ & $\begin{array}{l}0.74^{\text {cd }} \\
(0.02)\end{array}$ \\
\hline Leu & $\begin{array}{l}1.71^{\mathrm{c}} \\
(0.08)\end{array}$ & $\begin{array}{l}1.97^{\mathrm{ab}} \\
(0.05)\end{array}$ & $\begin{array}{l}1.77^{\mathrm{bc}} \\
(0.06)\end{array}$ & $\begin{array}{c}1.70^{c} \\
(0.06)\end{array}$ & $\begin{array}{l}1.93^{\mathrm{ab}} \\
(0.05)\end{array}$ & $\begin{array}{c}2.11^{\mathrm{a}} \\
(0.04)\end{array}$ & $\begin{array}{l}1.82^{b c} \\
(0.02)\end{array}$ & $\begin{array}{l}1.94^{\mathrm{ab}} \\
(0.04)\end{array}$ & $\begin{array}{c}2.07^{\mathrm{a}} \\
(0.05)\end{array}$ & $\begin{array}{l}1.80^{b c} \\
(0.05)\end{array}$ \\
\hline Tyr & $\begin{array}{c}0.44^{b} \\
(0.02)\end{array}$ & $\begin{array}{l}0.50^{\text {ab }} \\
(0.02)\end{array}$ & $\begin{array}{c}0.46^{\mathrm{b}} \\
(0.02)\end{array}$ & $\begin{array}{c}0.45^{\mathrm{b}} \\
(0.02)\end{array}$ & $\begin{array}{l}0.50^{\mathrm{ab}} \\
(0.02)\end{array}$ & $\begin{array}{c}0.55^{\mathrm{a}} \\
(0.01)\end{array}$ & $\begin{array}{c}0.47^{b} \\
(0.01)\end{array}$ & $\begin{array}{l}0.49^{a b} \\
(0.02)\end{array}$ & $\begin{array}{l}0.50^{\mathrm{ab}} \\
(0.02)\end{array}$ & $\begin{array}{c}0.47^{b} \\
(0.02)\end{array}$ \\
\hline Phe & $\begin{array}{c}0.61^{\mathrm{d}} \\
(0.02)\end{array}$ & $\begin{array}{l}0.69^{a b} \\
(0.02)\end{array}$ & $\begin{array}{l}0.62^{\mathrm{cd}} \\
(0.02)\end{array}$ & $\begin{array}{c}0.61^{\mathrm{d}} \\
(0.02)\end{array}$ & $\begin{array}{l}0.72^{\mathrm{ab}} \\
(0.02)\end{array}$ & $\begin{array}{c}0.75^{\mathrm{a}} \\
(0.02)\end{array}$ & $\begin{array}{l}0.67^{b c d} \\
(0.01)\end{array}$ & $\begin{array}{l}0.68^{b c} \\
(0.02)\end{array}$ & $\begin{array}{l}0.72^{a b} \\
(0.02)\end{array}$ & $\begin{array}{c}0.66^{\text {bcd }} \\
(0.02)\end{array}$ \\
\hline Lys & $\begin{array}{c}1.55^{\mathrm{e}} \\
(0.06)\end{array}$ & $\begin{array}{l}1.79^{\text {abc }} \\
(0.04)\end{array}$ & $\begin{array}{l}1.60^{\text {de }} \\
(0.04)\end{array}$ & $\begin{array}{c}1.55^{\mathrm{e}} \\
(0.04)\end{array}$ & $\begin{array}{l}1.78^{\mathrm{abc}} \\
(0.05)\end{array}$ & $\begin{array}{c}1.91^{\mathrm{a}} \\
(0.03)\end{array}$ & $\begin{array}{l}1.66^{\text {cde }} \\
(0.03)\end{array}$ & $\begin{array}{l}1.74^{\mathrm{bcd}} \\
(0.04)\end{array}$ & $\begin{array}{l}1.87^{\mathrm{ab}} \\
(0.04)\end{array}$ & $\begin{array}{l}1.67^{\mathrm{cde}} \\
(0.05)\end{array}$ \\
\hline His & $\begin{array}{c}0.60^{d} \\
(0.03)\end{array}$ & $\begin{array}{c}0.71^{\text {be }} \\
(0.02)\end{array}$ & $\begin{array}{l}0.65^{\mathrm{cd}} \\
(0.02)\end{array}$ & $\begin{array}{c}0.59^{d} \\
(0.01)\end{array}$ & $\begin{array}{c}0.62^{d} \\
(0.01)\end{array}$ & $\begin{array}{l}0.73^{\mathrm{ab}} \\
(0.02)\end{array}$ & $\begin{array}{c}0.61^{\mathrm{d}} \\
(0.02)\end{array}$ & $\begin{array}{l}0.70^{\mathrm{bc}} \\
(0.02)\end{array}$ & $\begin{array}{c}0.77^{a} \\
(0.01)\end{array}$ & $\begin{array}{c}0.64^{d} \\
(0.01)\end{array}$ \\
\hline Arg & $\begin{array}{l}1.12^{\mathrm{cd}} \\
(0.04)\end{array}$ & $\begin{array}{l}1.25^{a b c} \\
(0.04)\end{array}$ & $\begin{array}{l}1.12^{\text {cd }} \\
(0.03)\end{array}$ & $\begin{array}{c}1.08^{d} \\
(0.03)\end{array}$ & $\begin{array}{l}1.26^{a b} \\
(0.03)\end{array}$ & $\begin{array}{c}1.35^{a} \\
(0.03)\end{array}$ & $\begin{array}{l}1.20^{\mathrm{bcd}} \\
(0.02)\end{array}$ & $\begin{array}{l}1.23^{b c} \\
(0.03)\end{array}$ & $\begin{array}{l}1.31^{a b} \\
(0.03)\end{array}$ & $\begin{array}{l}1.20^{\text {bcd }} \\
(0.03)\end{array}$ \\
\hline Pro & $\begin{array}{l}0.76^{\mathrm{bc}} \\
(0.03)\end{array}$ & $\begin{array}{c}0.78^{b} \\
(0.02)\end{array}$ & $\begin{array}{c}0.71^{\mathrm{c}} \\
(0.02)\end{array}$ & $\begin{array}{c}0.70^{\mathrm{c}} \\
(0.01)\end{array}$ & $\begin{array}{l}0.80^{\mathrm{ab}} \\
(0.02)\end{array}$ & $\begin{array}{c}0.88^{\mathrm{a}} \\
(0.02)\end{array}$ & $\begin{array}{l}0.83^{\mathrm{ab}} \\
(0.03)\end{array}$ & $\begin{array}{l}0.80^{\mathrm{ab}} \\
(0.02)\end{array}$ & $\begin{array}{l}0.81^{\mathrm{ab}} \\
(0.02)\end{array}$ & $\begin{array}{l}0.81^{\mathrm{ab}} \\
(0.02)\end{array}$ \\
\hline Total amino acids & $\begin{array}{l}16.73^{\mathrm{d}} \\
(0.60)\end{array}$ & $\begin{array}{c}18.86^{\mathrm{hc}} \\
(0.46)\end{array}$ & $\begin{array}{l}16.95^{\mathrm{d}} \\
(0.41)\end{array}$ & $\begin{array}{l}16.34^{\mathrm{d}} \\
(0.42)\end{array}$ & $\begin{array}{c}18.79^{\mathrm{bc}} \\
(0.45)\end{array}$ & $\begin{array}{l}20.44^{\mathrm{a}} \\
(0.37)\end{array}$ & $\begin{array}{c}17.95^{\mathrm{cd}} \\
(0.27)\end{array}$ & $\begin{array}{c}18.56^{\mathrm{bc}} \\
(0.44)\end{array}$ & $\begin{array}{c}19.78^{\mathrm{ab}} \\
(0.41)\end{array}$ & $\begin{array}{c}17.94^{\mathrm{cd}} \\
(0.43)\end{array}$ \\
\hline
\end{tabular}

${ }^{a-f}$ Means within the same row having the different superscript were significantly different $(p<0.05)$.

*A, Abjin; B, Bosup; C, Cheggt; D, Dngsim; G, Guri; H, Hongduke; M, Moksim; S, Sulgit; U, Udoon; Y, Yangji.

"Mean (SE).

glutamate 함량이 가장 높은 수준으로 존재하였고 그 다음 으로 aspartate, leucine 및 lysin 순으로 높게 나타났다 $(p<0.05)$. 손(2008)이 한우의 안심, 등심, 채끝, 목심, 앞다 리, 우둔부위의 아미노산 함량을 분석한 결과에서도 glutamic acid 함량이 가장 높았고 다음으로 aspartic acid, leucine, 홍두깨부위는 cysteine, aspartate, threonine, serine, glutamate, glycine, alanine, valine, leucine, Iso-leucine, tyrosine, phenylalanine, lycine, arginine 및 proline 함량이 다른 부 위와 비교하여 가장 높은 것으로 나타났다 $(p<0.05)$. 홍두 깨 다음으로 우둔부위에 cysteine, methionine, aspartate, leucine 및 histidine 함량이 높은 수준으로 나타났다 $(p<0.05)$. 반면에 등심부위는 분석된 모든 아미노산 종류의 함량이
다른 부위와 비교하여 가장 낮은 것으로 나티났다 $(p<0.05)$. 등심 다음으로 업진부위의 경우 cysteine, methionine, aspartate, valine, leucine, Iso-leucine, tyrosine, phenylalanine, lycine 및 proline 함량이 가장 낮은 것으로 분석되 었다 $(p<0.05)$.

단백질의 주요 급원은 동물성 식품인 어육류, 유제품, 난류와 콩과 견과류의 식물성 식품이 있다. 식물성 식품 은 동물성 식품에 비해 단백질의 질이 낮고 그 함량도 적 지만 주식으로 사용되어 단백질 섭취의 상당부분을 차지 한다. 일반적으로 생물체내에서 생합성이 되지 않는 아미 노산을 필수 아미노산(essential amino acid)이라고 하며 우 리 몸이 정상적으로 기능하기 위해서는 이러한 필수 아 
미노산을 반드시 음식물을 통해 섭취해야 하는 아미노산 이다. 필수아미노산에는 arginine, histidine, isoleucine, leucine, lysine, methionine, phenylalanine, threonine, tryptophan, valine 등이 포함되어 있는데, 이 중 arginine이 유 아만 해당되고 성인은 해당되지 않는다고 한다(손, 2008). 본 연구결과 거세한우고기에는 부위별로 함량에는 다소 차이가 있으나 이러한 필수아미노산이 골고루 함유되어 있는 것을 알 수 있었으며 10 부위 중에서 특히 홍두깨부 위에 methionine과 histidine을 제외한 필수아미노산이 가 장 풍부하게 함유되어 있는 것으로 나타났으며, methionine 과 histidine은 우둔부위에 가장 높게 함유되어 있는 것으 로 나타났다 $(p<0.05)$.

필수아미노산 중 valine, leucine 및 isoleucine은 그 분자 구조의 특성을 나타내는 명칭인 '곁가지 아미노산(BCAA, branched chain amino acids)'으로 불리는데 BCAA는 다른 필수아미노산들은 간에서 산화되어지는 것과는 달리 골격 근에서 산화되어 운동시 수축하는 골격근에서 사용되는데 운동선수들이 훈련양이 많은 기간 동안에 탄수화물과 $\mathrm{BCAA}$ 를 섭취하게 되면 훈련기간 동안 가장 최적의 단백 질 균형을 유지할 수 있다고 하였다(김 등, 1995). 본 연 구에서 우둔과 홍두깨에 이러한 $\mathrm{BCAA}$ 함량도 많은 것으 로 분석되었다.

\section{무기물}

쇠고기에는 $\mathrm{Ca}, \mathrm{P}, \mathrm{K}, \mathrm{Fe}, \mathrm{Zn}$ 등과 같은 무기물들이 함 유된 것으로 알려져 있는데(김 등, 2007) 이 중에서 $\mathrm{Ca}$, $\mathrm{Fe}$ 및 $\mathrm{Zn}$ 함랑을 분석한 결과가 Table 4에 나타나 있다. 10 부위간에 $\mathrm{Ca}$ 함량에는 유의적인 차이가 없었다 $(p>0.05)$. $\mathrm{Fe}$ 함량은 $15.09 \mathrm{mg} / \mathrm{kg}$ 으로 가장 낮은 함량을 가진 업진 부위를 제외한 다른 부위에는 20.49-26.68 mg/kg으로 포함 되어 있었으며 나머지 9 부위간에는 유의적인 차이가 없 는 것으로 나타났다 $(p<0.05) . \mathrm{Zn}$ 함량은 꾸리부위가 가장 높게 함유되어 있었고 채끝, 업진, 홍두깨, 설깃 및 우둔 부위에는 다른 부위와 비교하여 가장 낮게 함유되어 있는 것으로 분석되었다 $(p<0.05)$. 쇠고기는 단백질 뿐 아니라 $\mathrm{Zn}$ 및 $\mathrm{Fe}$ 등과 같은 무기물도 풍부한 식품으로 알려져 있 으며(Bodwell, 1986; Harrington, 1994) 특히 철분은 $100 \mathrm{~g}$ 당 0.71-1.22 mg인 돼지고기와 비교하여 $100 \mathrm{~g}$ 당 $1.66-2.92$ $\mathrm{mg}$ 수준으로 많이 함유되어 있다고 보고되어 있다(손, 2008). 일반적으로 철은 미량영양소로서 철의 급원으로 가 장 촣은 식품은 대부분 헴철을 함유하고 있는 육류, 어패 류, 가금류이다. 특히 동물성 식품은 생체 이용효율이 높 은 헴(heme)철의 형태가 약 $40 \%$ 정도 함유 되어 있어, 생 체 이용효율이 낮은 비헴(non-heme)철의 형태로 함유된 식물성식품보다 좋은 철의 급원이 된다. 아연은 체내에 $1.5-2.5 \mathrm{~g}$ 정도로 소량 존재하지만 DNA나 RNA와 같은 핵 산의 합성에 관여하고, 단백질의 대사와 합성을 조절하여
Table 4. Ca, Fe, and $\mathrm{Zn}$ contents $(\mathrm{mg} / \mathrm{kg})$ of Hanwoo steer beef with $1^{++}$grade by different cut $(n=10)$

\begin{tabular}{cccc}
\hline \hline Cut & $\begin{array}{c}\mathrm{Ca} \\
(\mathrm{mg} / \mathrm{kg})\end{array}$ & $\begin{array}{c}\mathrm{Fe} \\
(\mathrm{mg} / \mathrm{kg})\end{array}$ & $\begin{array}{c}\mathrm{Zn} \\
(\mathrm{mg} / \mathrm{kg})\end{array}$ \\
\hline \multirow{2}{*}{ Abjin } & ${ }^{1} 55.79$ & $15.09^{\mathrm{b}}$ & $37.97^{\mathrm{c}}$ \\
& $(6.06)$ & $(1.48)$ & $(2.30)$ \\
Bosup & 57.44 & $26.68^{\mathrm{a}}$ & $41.98^{\mathrm{bc}}$ \\
& $(6.55)$ & $(1.44)$ & $(1.30)$ \\
Cheggt & 47.63 & $22.16^{\mathrm{a}}$ & $34.55^{\mathrm{c}}$ \\
& $(4.51)$ & $(2.24)$ & $(2.05)$ \\
Dngsim & 50.91 & $20.93^{\mathrm{a}}$ & $42.61^{\mathrm{bc}}$ \\
& $(3.45)$ & $(1.45)$ & $(1.66)$ \\
Guri & 69.20 & $24.51^{\mathrm{a}}$ & $50.56^{\mathrm{a}}$ \\
& $(11.92)$ & $(1.76)$ & $(2.72)$ \\
Hongduke & 64.82 & $20.76^{\mathrm{a}}$ & $38.06^{\mathrm{c}}$ \\
& $(10.63)$ & $(1.66)$ & $(1.70)$ \\
Moksim & 70.69 & $20.49^{\mathrm{a}}$ & $46.61^{\mathrm{ab}}$ \\
& $(6.83)$ & $(0.83)$ & $(2.12)$ \\
Sulgit & 50.19 & $23.03^{\mathrm{a}}$ & $37.11^{\mathrm{c}}$ \\
& $(3.48)$ & $(0.98)$ & $(0.91)$ \\
Udoon & 48.14 & $26.27^{\mathrm{a}}$ & $38.62^{\mathrm{c}}$ \\
& $(1.94)$ & $(1.47)$ & $(1.47)$ \\
Yangii & 55.24 & $22.70^{\mathrm{a}}$ & $41.35^{\mathrm{bc}}$ \\
& $(3.69)$ & $(1.48)$ & $(1.56)$ \\
\hline
\end{tabular}

${ }^{\mathrm{a}-\mathrm{b}}$ Means within the same column having the different superscript were significantly different $(p<0.05)$.

${ }^{1)}$ Mean (SE).

상처의 회복을 돕고 성장이나 면역 기능을 원활히 하는데 필요한 필수적인 미량원소이다(최 등, 2003). 아연의 주된 급원 역시 동물성 식품으로 쇠고기를 비롯한 육류, 간, 굴 - 게 - 새우 등의 패류 등이 아연의 좋은 공급원이다. 곡류 등의 식물성 식품은 아연의 급원이기는 하나 육류, 어패류 등의 동물성 식품에 함유된 아연은 체내에서의 이 용률이 높다고 알려진 반면 식물성 식품은 아연의 이용률 이 대체로 낮은데 이는 곡류 등에 들어있는 피틴산(phytate) 은 아연 홉수율을 감소시키기 때문이다. 피틴산은 아연과 결합하여 불용성복합체를 형성하며, 칼슘이 고농도로 존 재할 때에는 불용성 복합체의 형성이 더욱 중가하여 아연 의 흡수를 방해한다고 하였다(LOnnerdal, 2000). 아연은 결핍시 성장이나 근육발달이 지연되고, 생식기 발달이 저 하된다. 면역기능 또한 저하되고, 상처의 회복이 지연되 며, 식욕부진 및 미각과 후각의 감퇴가 따른다고 하였다. 또한, 아연은 당뇨병의 주요 대사조절 지표인 인슐린의 구 조적 역할뿐만 아니라 인슐린 호르몬의 합성 및 저장, 분 비에 필수적이어서 섭취를 권장섭취량만큼 높이기 위해 동물성 단백질을 적정 수준 섭취하도록 하는 것이 필요하 다고 하였다(윤 등, 2007).

\section{요 약}

본 연구는 거세한우 고기의 부위별 성분조성 및 육질특 
성을 조사하고자 거세한우 10 두(28-30개월)에서 10부위(업 진, 보섭, 채끝, 등심, 꾸리, 홍두깨, 목심, 설깃, 양지, 우 둔)를 선정하여 성분조성 및 육질특성을 분석하였다. 10 부 위의 $\mathrm{pH}$ 는 5.46-5.64 범위였으며 꾸리부위가 5.64로 가장 높았던 반면에 보섭, 채끝, 및 우둔이 각각 $5.49,5.46,5.47$ 로 다른 부위와 비교했을 때 가장 낮게 나타났다 $(p<0.05)$. 일반성분조성을 분석한 결과 단백질 함량은 홍두깨 부위 가 $21.15 \%$ 로 가장 높은 반면에 등심부위의 단백질 함량 은 $16.94 \%$ 로 가장 낮은 것으로 분석되었고 $(p<0.05)$, 지방 함량은 등심부위가 $24.74 \%$ 로 가장 높은 반면에 꾸리, 홍 두깨 및 우둔부위의 지방함량은 유의적으로 가장 낮은 수 준을 나타냈다 $(p<0.05)$. 육색은 L값(백색도)만이 등심부위 가 유의적으로 가장 높게 나타났고 $(p<0.05)$ 다른 부위간 에는 L값, a값(적색도) 및 b값(황색도)에서 모두 유의적인 차이가 없는 것으로 나타났다(p>0.05). $1^{++}$등급 거세우고 기의 10 부위의 가열감랑을 분석한 결과 꾸리, 홍두깨, 우 둔, 양지부위가 높게 나타난 반면에 채끝부위가 $21.44 \%$ 로 유의적으로 가장 낮게 나타났다 $(p<0.05)$. 전단력은 업진부 위가 $6.24 \mathrm{inch}^{2} / \mathrm{kg}$ 으로 가장 높게 나타났고 등심과 채끝부 위가 각각 3.45 및 $3.50 \mathrm{inch}^{2} / \mathrm{kg}$ 으로 가장 낮게 나타났다 $(p<0.05)$. 보수력은 10 부위간에 유의적인 차이가 없는 것 으로 나타났다( $p>0.05)$. 총 아미노산 함량은 홍두깨 부위 가 가장 높게 나타났으며 특히 methionine과 histidine을 제 외한 필수아미노산이 풍부하게 함유되어 있는 것으로 나 타났다. Methionine과 histidine은 우둔부위에 가장 높게 함 유되어 있는 것으로 나타났다 $(p<0.05)$. 무기물 분석결과 10 부위간에 $\mathrm{Ca}$ 함량에는 유의적인 차이가 없었으나 $\mathrm{Fe}$ 함랑은 $15.09-26.68 \mathrm{mg} / \mathrm{kg}$ 으로 포함되어 있었으며 $(p<0.05)$, $\mathrm{Zn}$ 함량은 꾸리부위가 $50.56 \mathrm{mg} / \mathrm{kg}$ 으로 10 부위 중에서 가 장 높게 함유되어 있었다.

\section{감사의 글}

이 논문은 2007년도 농촌진흥청 축산콰학원 경상연구비 에 의하여 연구되었으며 이에 감사드립니다.

\section{참고문헌}

1. Ansorena, D., Pena, M. P. D., Astiasaran, I., and Bello, J. (1997) Colour evaluation of chorize de pamplona, a spanish dry fermented sausage : comparison between the CIE $\mathrm{L}^{*} \mathrm{a}^{*} \mathrm{~b}$ " and the hunter Lab systems with illuminants D65 and C. Meat Sci. 46, 313-318.

2. Animal Products Grading Service. (2008) Grade information. http://www.apgs.co.kr/gradeinfo/statistics (assessed on July 30,2008 ).

3. AOAC. (1995) Official methods of analysis, 15th ed. Association of Official Analytical Chemists, Washington, DC.
4. Baardseth, P., Skrede, G., Naes, T., Thomassen, M. S., Iversen, A., and Kaaber, L (1988) A comparison of CIE $L^{*} \mathrm{a}{ }^{*} \mathrm{~b}^{*}$ values obtained from two different instruments on seeral food commodities, J. Food Sci. 53, 1737-1742.

5. Berry, B. W. (1993) Tenderness of beef loin steaks as influences by marbling level, removal of subcutaneous fat and cooking method. J. Anim. Sci. 71, 2412-2419.

6. Bodwell, C. E. (1986) Nutritional composition and value of meat products. Muscle as Food 321-328.

7. Bowers, J. A., Craig, J. A., Kropf, D. H., and Tucker, T. J. (1987) Flavor, color and other characteristics of beef longissimus muscle heated to seven internal temperatures between $55^{\circ} \mathrm{C}$ and $85^{\circ} \mathrm{C}$. J. Food Sci. 52, 533-536.

8. Breidenstein, B. B., Cooper, C. C. Evans, R. G., and Bray, R. W. (1968) Influence of marbling and maturity on palatability of beef muscle. 1. Chemical and organoleptic consideration. J. Anim. Sci. 27, 1532-1536.

9. Cho, S. H., Park, B. Y., Kim, J. H., Choi, Y. H., Seong, P. N., Chung, W. T., Chung, M. O., Kim, D. H., and Ahn, C. N. (2007) Nutritional composition and physico-chemical meat quality properties of Korean Hanwoo bull beef. Kor. J. Anim. Sci. Technol. 49(6), 871-880.

10. Chrystall, B. (1994) Meat texture measurement. In: Advances in Meat Research, Vol. 9, pp. 316.

11. Eikelenboom, G., Hoving-Bolink, A. H., van der Wal, P. G. (1996) The eating quality of pork. 2. The influence of intramuscular fat. Fleischwirstschaft 76, 517-518.

12. Field, R. A. (1971) Effect of castration on meat quality and quantity. J. Anim. Sci. 32, 849-858.

13. Flores, M., Armero, F., Aristoy, M-C., and Toldrá, F. (1999) Sensory characteristic of cooked pork loin as affected by nucleotide content and post-mortem meat quality. Meat Sci. 51, 53-59.

14. Gullett, E. A., Buttenham, S., and Hore, T. (1996) Effect of age and cut on consistency of tenderness and leanness of beef. Food Quality and Preferences 7, 37-45.

15. Harrington, G. (1994) Consumer demands: major problem facing industry in a consumer-driven society. Meat Sci. 36, 5-8.

16. Hutchings, J. B. and Illford, P. J. (1988) $\mathrm{pH}$. The perception of food texture-the philosophy of the breakdown path, J. Texture Studies. 19, 103-109.

17. Ibanez, C., Quintanilla, L., Irigoyen, A., Garcia-Jalon, I., Cid, C., Astiasaran, I., and Bello, J. (1995) Partial replacement of sodium chloride with potassium chloride in dry fermented sausage : Influence on carbohydrate fermentation and the nitrosation process. Meat Sci. 40, 45-53.

18. Jacobs, J. A., Miller, J. C., Sauters, E. A. Howes, A. D., Araji, A. A., Gregory, T. L., and Hust, C. E. (1977) Bulls versus steers. II. Palatability and retail acceptance. J. Anim. Sci. 45, 699-702.

19. Kim, D. G., Jung, K. K., Sung, S. K., Choi, S. B., Kim, S. G., Kim, D. Y., and Choi, B. J. (1996) Effects of castration on the carcass characteristics of Hanwoo and Holstein. Kor, J. Anim. Sci. Technol. 38(3), 239-248.

20. Kim, J. W., Cheon, Y. H., Jang, A. R., Lee, S. O., Min, J. S., 
and Lee, M. (2002) Determination of physico-chemical properties and quality attributes of Hanwoo beef with grade and sex. Kor. J. Anim. Sci. Technot. 44(5), 599-606.

21. Landon, M. E., Hedrick, H. B., and Thompson, G. B. (1978) Live animal performance and carcass characteristics of beef bullocks and steer. J. Anim. Sci. 47, 151-155.

22. Lizaso, G., Hernadez, B., Chasco, J., Insausti, K., Beriain, M. J., and Purroy, A. (1996) Meat colour from pirencia steers and heifers after vacuum packaging. Proc. 42nd ICOMST. 1, 98-99.

23. LOnnerdal, B. (2000) Dietary factors influencing zinc absorption, J. Nutr. 130, 1378S-1383S.

24. Melton, S. L. (1990) Effect of feed on flavor of red meat, a review, J. Anim. Sci. 68, 4421-4435.

25. Mercier, Y., Gatellier, P., Viau, M., Remignon, H., and Renerre, M. (1998) Effect of Dietary fat and vitamin E on colour stability and on lipid and protein oxidation in turkey Meat during storage. Meat Sci. 48, 301-318.

26. National Livestock and Meat Board. (1988) Meat evaluation handbook. Chicago, IL.

27. Padre, R. G., Aricetti, J. A., Moreira, F. B., Mizubuti, I. Y., Prado, I. N., Visentainer, J. V., Souza, N. E., and Matsushita, M. (2006) Fatty acid profile, and chemical composition of Longissimus muscle of bovine steers and bulls finished in pasture system. Meat Sci. 74, 242-248.

28. Rodrigues, V. C. and Andrade, I. F. 2004. Características fisico-químicas da carne de bubalinos e de bovinos castrados e inteiros. Revist Brasileira de Zootecnia, 33(6), 1839-1849 (Suppl. 1).

29. Ryoichi, S., Degychi, T., and Nagata, Y. (1993) Effectiveness of the filter paper press methods for determining the water holding capacity of meat. Fleischwirtsch 73, 1399.

30. Sakata, R. and Nagata, Y. (1992) Heme pigment content in meat as affected by the addition curing agents. Meat $S_{c i .}$ 32, 343-350.

31. Santamaria, I., Lizarraga, T., Astiasaran, I., and Bello, J. (1992) Contribution alproblema del desarrollo del color en al Chorizo de Pamplona : comportamiento de nitritos, nitratos y pigmentos carnicos. Alimentaria 1, 23-26.

32. SAS. (1996). SAS STAT User's Guide, Statistics, Cary NC.

33. Watson, M. J. (1969) The effects of castration on the growth and meat quality of grazing cattle. Aust. J. Exp. Agr. Husb. 9, 164-167.

34. Weninger, J. H. and D. Steinhauf. (1968) Meat quality in respect to carcass evaluation in cattle. World Rev. Anim. Prod. 4, 87.

35. Wheeler, T. L., Shackelford, S. D., and Koohmaraie, M. (2000) Relationship of beef longissimus tenderness classes

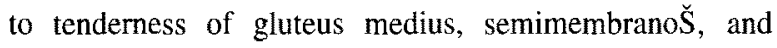
biceps femoris. J. Anim. Sci. 78, 2856-2861.
36. Yang, A., Larsen, T. W., and Tume, R. K. (1992) Carotenoid and retinol concentration in serum adipose tissue and liver and carotinoid transport in sheep, goats and cattle. Aust. $J$. Agric. Res. 43, 1809-1817.

37. Yang, A., Larsen, T. W., Powell, V. H., and Tume, R. K. (1999) A comparison of fat composition of Japanese and long-term grain-fed Australian steers. Meat Sci. 51, 1-9.

38. 강종옥, 정유성, 조규석, 坂田亮一, 유상하. (1992) 한우 육과 수입우육의 감별검사에 관한 연구. 1. 출하전의 한 우육과 수입우육의 육색소 및 미세구조. 한국축산하회지 34, 121-126.

39. 강종옥, 최도영, 오홍록, 김기환. (1999) 등급별 국내산 한우육과 국별 수입우육의 물리화학적 특성비교; 육색, 지방색, 성숙도에 관한 고찰. 한국동물지원과학회지 41, 555-562.

40. 김경태, 배근아, 김창근. (1995) 지구성 운동과 $\mathrm{BCAA}$ 의 투여. 체욱콰학연구소논문집 14, 187-198.

41. 김병철, 오세종. (1990) 한우육과 홀스타인육의 이화학적 성질에 관한 비고연구. 고려대하교 농림논집 107.

42. 김용곤, 유영모, 김진형, 안종남. (2007) 식육의 테마상식. 농촌진흥청 축산과학원 문성사

43. 백봉현, 이병석, 강희설, 김용곤, 박명국, 이근상. (1992) 한우의 거세시기가 육질 및 육생산에 미치는 영향. 농시 연보. p.62.

44. 손숙미. (2008) 한우 부위별 영양학적 가치연구. 한우협 회기금 연구사업 최종보고서.

45. 유익종, 박병성, 김수정, 전기홍, 김영붕, 이남형, 정재홍. (1993) 한우육의 우수성 발굴에 관한 연구. (사)한국식품 개발연구원

46. 윤진숙, 이정희. (2007) 제 2형 당노병 여성의 아연영양 관리방안: 단백질 및 피틴산 섭취와의 관련성. 대한영양 사협회 하술지 13, 301-310.

47. 이길왕, 김용곤, 정숙근, 차장옥, 백영기, 송계원. (1981) 쇠고기의 분할방법 및 해부학적 특성과 이용법 규명에 관한연구. 축시연보 580 .

48. 최미혜 (2003) 21세기 영양학, 교문사, 319-335.

49. 한기동, 김대곤, 김수민, 안동현, 성삼경. (1996) 등급에 따른 한우육의 숙성 중 이화학 및 형태학적 특성변화. 한 국동물자원과학회지 38, 589-596.

50. 농림기술개발사업최종보고서. (2001) 육류의 저장 및 유 통개선을 위한 기술개발, 농림부.

51. 소 및 돼지고기 부분육 분할 정형 지침서. (1997) 농촌 진흥청 축산과학원.

52. 三律本充, 山下良弘, 三橋忠由, 中西直人. (1987) 黑手和 榽去勢牛における胸長筋の理化學的特性と格付等級との 閣係。中國試報。 B，29，35.

53. 吉田正三郎, 上田敬介, 寺田降慶, 田中彰治. 小尺忍, (1968) 若䯍肥育における堆牛と去勢牛の產肉性の比較，中國農 試報, 16, 873 .

(2008. 7.7 접수/2008. 8. 18 수정/2008. 9. 6 채택) 